Tomasz PeŁech

Uniwersytet WarszaWski / University of WarsaW

Université Clermont-Auvergne

iD https://orcid.org/0000-0002-3722-568X

\title{
Baldwin z Boulogne w opinii Anny Komneny na kartach Aleksjady
}

\section{Abstract}

\section{Baldwin of Boulogne in the Anna Komnene's opinion on the pages of Alexiad}

$\mathrm{T}$ he article takes up the issue of Anna Komnene's opinion of Baldwin of Boulogne in her Alexiad. The daughter of Alexius I represents the Byzantine view of the world, in which the Latins began to play an increasingly greater and more visible role at the end of the $11^{\text {th }} \mathrm{c}$., especially in connection with the crusade movement that began to emerge from 1095. It turned out to be important to involve the Frankish states established in Outremer into the orbit of imperial politics. Baldwin of Boulogne, Count of Edessa from 1097, who in 1100 was crowned the first Latin king of Jerusalem, did not escape Byzantine attention. Baldwin of Boulogne appears four times in Alexiad, giving the opportunity to formulate the opinion about him on the pages of the work. The article presents the thesis that Anna Komnene does not present him as a leading figure in her work. Baldwin of Boulogne plays a rather modest and marginal role, whether related to narrative needs or in connection with the Byzantine political efforts to regain Antioch from the hands of the Normans. This suggests that from the point of view of Constantinople, he was not a particularly important player on the political scene, both during the First Crusade and even after his election as king of Jerusalem. Baldwin emerges from the pages of Alexiad as a character with two faces: on the one hand, he is a confident, energetic commander, characterized by cunning and broader strategic thinking, and on the other hand, he is a greedy barbarian, suffering military defeats. Therefore, Baldwin's presentation does not differ significantly from the general image of Latins in the Byzantine Empire in the $12^{\text {th }} \mathrm{c}$.

Keywords: Baldwin of Boulogne, Alexiad, Anna Komnene, Crusades, Middle Ages 
STRESZCZENIE

\begin{abstract}
A rtykuł porusza kwestię opinii Anny Komneny o Baldwinie z Boulogne w jej Aleksjadzie. Córka Aleksego I reprezentuje bizantyński ogląd świata, w którym pod koniec XI w. coraz większą i widoczniejszą rolę zaczęli odgrywać Łacinnicy, zwłaszcza w związku z rodzącym się od 1095 r. ruchem krucjatowym. Istotne okazało się wciagnięcie państw frankijskich powstałych w Outremer w orbitę cesarskiej polityki. Bizantyńskiej uwadze nie uszedł Baldwin z Boulogne, hrabia Edessy od 1097 r., który w 1100 r. koronował się na pierwszego łacińskiego króla Jerozolimy. Czterokrotne pojawia się w Aleksjadzie, dając możliwość sformułowania jego oceny na kartach dzieła. W artykule została przedstawiona teza, że Anna Komnena nie prezentuje go jako pierwszoplanowej postaci w swoim utworze. Baldwin $z$ Boulogne odgrywa raczej skromna i marginalną rolę, związana bądź to $z$ potrzebami narracyjnymi, bądź też w związku $z$ bizantyńskimi zabiegami politycznymi, mającymi na celu odzyskanie Antiochii z rąk Normanów. Pozwala to przypuszczać, że z punktu widzenia Konstantynopola nie był on szczególnie ważnym graczem na scenie politycznej, zarówno w czasie I krucjaty, jak i nawet po wyborze na króla Jerozolimy. Baldwin wyłania się z kart Aleksjady jako postać o dwóch obliczach: $z$ jednej strony jest dobrym, energicznym dowódca, charakteryzującym się sprytem i szerszą myślą strategiczna, a $z$ drugiej to chciwy barbarzyńca, ponoszący jednak porażki militarne. Jego przedstawienie nie odbiega więc znacząco od ogólnego wyobrażenia Łacinników w Bizancjum w XII w.
\end{abstract}

Słowa kluczowe: Baldwin z Boulogne, Aleksjada, Anna Komnena, wyprawy krzyżowe, średniowiecze

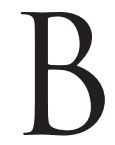

aldwin z Boulogne, hrabia Edessy (1097-1100) oraz król Jerozolimy (1100-1118), jest postacią, która doczekała się licznych wzmianek w źródłach łacińskich, arabskich, syryjskich, ormiańskich czy bizantyńskich. W historiografii przedstawia się go jako budowniczego Królestwa Jerozolimskiego, zdolnego stratega i wodza, zdobywcę wybrzeża palestyńskiego, przywódcę Franków w Outremer, niewahającego się wejść w konflikt z Kościołem, aby osiagnąc partykularne interesy polityczne ${ }^{1}$. Niemniej

${ }^{1}$ Por. H.E. Mayer, Études sur l'histoire de Baudouin Ier, roi de Jérusalem, [w:] Mélanges sur l'histoire du royaume latin de Jérusalem (Mémoires de l'Académie des inscriptions et Belles Lettres, Nouvelle série 5), Paris 1984, s. 10-91; A.V. Murray, The Crusader Kingdom of Jerusalem: A Dynastic History 1099-1125, Oxford 2000, s. 30-36, 94-116; Ch. Tyerman, God's War. A New History of the Crusades, London-New York 2007, s. 185-189, 200-211; S. Ru ncim a n, Dzieje wypraw krzyżowych, t. II (Królestwo Jerozolimskie i frankijski Wschód 1100-1187), przekł. J. Schwakopf, Katowice 2009, s. 68-99. Najnowsza i właściwie jedyna pełna monografia na temat Baldwina I por. S.B. Edgington, Baldwin I of Jerusalem, 1100-1118, Abingdon-New York 2019. 
jednak zastanawia brak opracowań poświęconych ocenie i wizerunkowi Baldwina I w poszczególnych utworach, indywidualnych "światach tekstu" ${ }^{2}$ Artykuł stara się więc choć częściowo wypełnić tę lukę poprzez analizę opinii i stosunku Bizantyńczyków do pierwszego łacińskiego króla Jerozolimy.

Jedynym źródłem proweniencji bizantyńskiej opisującym I krucjatę $^{3}$, a przy tym wzmiankujacym Baldwina $z$ Boulogne, jest Aleksjada Anny Komneny (1083-1153)4. Dzieło, opisujące czyny

${ }^{2}$ O „świecie tekstu” por. P. Ricoeur, Język, tekst, interpretacja. Wybór pism, przekł. P. Graff, K. Rosner, Warszawa 1989, s. 224-245.

${ }^{3} \mathrm{~W}$ opisach I krucjaty inni bizantyńscy autorzy, jak Michał Glykas (Michaelis Glycae Annales, ed. I. Bekker, Bonnae 1836) oraz Teodor Skutariota (Anonymi Synopsis Chronike, ed. K. Sathas, Paris 1894 [przedruk: Athens 1972]), nie przekazuja żadnych informacji o Baldwinie $z$ Boulogne, a Jan Zonaras cała uwage poświęca Boemundowi (por. Ioannis Zonarae Epitome historiarum libri XIII-XVIII, ed. Th. Büttner-Wobst, Bonnae 1897, XVIII, 24, s. 749-751). Przejście krzyżowców przez Cesarstwo Bizantyńskie odnotował co prawda także Teofilakt z Ochrydy, ale wspomniał on tylko, że nie wie, jak go określić -

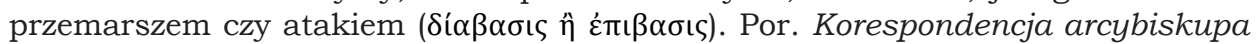
Teofylakta Ochrydzkiego, [w:] Testimonia najdawniejszych dziejów Słowian. Seria grecka, z. 4 (Pisarze z VIII-XII wieku), wyd. A. Brzóstkowska, W. Swoboda, Warszawa 1997, List nr 52, s. 219. Na tym tle warto przyjrzeć się ormiańskiej Kronice Mateusza z Edessy (ok. II poł. XI w. - 1144), która poświęca wiele miejsca Baldwinowi z Boulogne, gdyż jego działalność na terenach Syrii Północnej i Palestyny spotkała się z żywym zainteresowaniem lokalnych, wschodnich wspólnot chrześcijańskich, istniejących na peryferiach dawnych granic Cesarstwa Bizantyńskiego. Mateusz z Edessy zwraca uwage m.in. na znakomite pochodzenie Gotfryda z Bouillon i jego brata, którzy mieli pochodzić od rzymskich cesarzy (w istocie w ich żyłach, po kądzieli, płynęła krew Karola Wielkiego), a także znakomitą biegłość w sztuce wojennej i bezwzględność w walce $z$ wrogiem, co można dostrzec m.in. w masakrze populacji miasta Sarūj. Por. Matthew of Edessa, Armenia and the Crusades, Tenth to Twelfth Centuries: The Chronicle of Matthew of Edessa, transl. A.E. Dostourian, Lanham-New York-London 1993, 110, s. 164; 135, s. 178.

${ }^{4}$ Annae Comnenae Alexias, eds D.R. Reinsch, A. Kambylis, vol. I-II, Berolini-Novi Eboraci 2001 [dalej: Alexias]; Anna Komnena, Aleksjada, przekł. O. Jurewicz, t. I-II, Wrocław-Warszawa 2005 [dalej: Aleksjada]. Szerzej na temat Anny Komneny i jej Aleksjady por. G. Buckler, Anna Comnena. A Study, London 1929; A. Kambylis, Zum Programm der byzantinischen Historikerin Anna Komnene, [w:] Dorema: Hans Diller zum 70. Geburtstag: Dauer und Überleben des antiken Geistes, hrsg. K. Vourveres, A.D. Skiadas, Athens 1975, s. 127-146; Anna Komnene and Her Times, ed. T. Gouma-Peterson, London-New York 2000; J. Strzelczyk, "W purpurze urodzona" - Anna Komnena i Aleksjada, [w:] id e m, Pióro $w$ wattych dłoniach. O twórczości kobiet $w$ dawnych wiekach, t. II, Warszawa 2007, s. 148-194; S. Papaioannou, Anna Komnene's Will, [w:] Byzantine Religious Culture: Studies in Honor of Alice-Mary Talbot, eds D. Sullivan, E. Fisher, S. Papaioannou, Leiden-Boston 2012, s. 99-124; I. Stouraitis, Conceptions 
i panowanie ojca autorki, Aleksego I Komnena (1081-1118), powstało prawdopodobnie w latach 1148-1153, w czasie rząów Manuela I (1143-1180). Aleksjada, napisana klasyczna greka attycka, składa się z XV ksiag oraz prologu. Utwór charakteryzuje się zwartą kompozycja, ale można zauważyć pewne naruszenie proporcji w szczegółowości prezentowanych wydarzeń między księgami I-XIII (opisującymi lata 1072-1108) a XIV-XV (1108-1118). Autorka Aleksjady odznacza się ogromną erudycją, znajomością opisywanych rzeczy oraz znakomitym wykształceniem ${ }^{5}$. To pozwoliło jej na szczegółowe przedstawienie dziejów Cesarstwa Bizantyńskiego przełomu XI i XII w., a przy tym na uchwycenie zmian społecznych, kulturowych i politycznych w nim zachodzacych. Była naocznym świadkiem wielu wydarzeń. W wieku 13 lat mogła np. zaobserwować pochód wojsk I krucjaty, gdzie wśród krzyżowców pojawiających się w 1097 r. w Konstantynopolu znajdował się przyszły król Jerozolimy ${ }^{6}$.

of War and Peace in Anna Comnena's Alexiad, [w:] Byzantine War Ideology between Roman Imperial Concept and Christian Religion: Akten des Internationalen Symposiums (Vienna, 19-21 Mai 2011), eds J. Koder, I. Stouraitis, Vienna 2012, s. 69-80; P. Bu ckley, The Alexiad of Anna Komnene: Artistic Strategy in the Making of a Myth, Cambridge 2014; L. Neville, Anna Komnene: The Life and Work of a Medieval Historian, Oxford 2016; T. Pełech, Obraz „obcego” w Aleksjadzie Anny Komneny. Przypadek Normanów, Wrocław 2016.

5 Wskazówki na temat bogatej edukacji Anny Komneny można odnaleźć na kartach Aleksjady (Alexias, ПРО $А$ ОО, , 1, 2, s. 5-6), a także m.in. w mowie pogrzebowej sporządzonej na jej cześć przez Jerzego Tornikesa (R. Browning, An unpublished funeral oration on Anna Comnena, [w:] Aristotle Transformed: The Ancient Commentators and Their Influence, ed. R. Sorabji, London 1990, s. 393-406).

${ }^{6} \mathrm{Na}$ temat Aleksjady jako źródła do dziejów krucjat por. J. France, Anna Comnena, the Alexiad and the First Crusade, "Reading Medieval Studies” 1984, vol. X, s. 20-38; R.D. Thomas, Anna Comnena's account of the First Crusade, „Byzantine and Modern Greek Studies” 1991, vol. XV, s. 269-312; J. Sh e pard, Cross-Purposes: Alexius Comnenus and the First Crusade, [w:] The First Crusade: Origins and Impact, ed. J. Phillips, Manchester 1997, s. 107-129; P. Frankopan, Perception and Projection of Prejudice: Anna Comnena, the Alexiad and the First Crusade, [w:] Gendering the Crusades, eds S.B. Edgington, S. Lambert, Cardiff 2001, s. 59-76; P. Stephenson, Anna Comnena's Alexiad as a Source for the Second Crusade?, „Journal of Medieval History” 2003, vol. XXIX, s. 41-54; I. Kolovou, Anna Komnene and the Alexiad: The Byzantine Princess and the First Crusade, Barnsley 2020, s. 146-184. Por. również J. Dudek, Postawa arystokracji bizantyjskiej wobec idei krucjat w drugiej połowie XI wieku, [w:] Rycerstwo Europy środkowo-wschodniej wobec idei krucjat, red. W. Peltz, J. Dudek, Zielona Góra 2002, s. 139-158. 
Baldwinowi $z$ Boulogne $\mathrm{w}$ porównaniu $\mathrm{z}$ Boemundem, synem Roberta Guiscarda ${ }^{7}$, Anna Komena nie poświęca aż tyle uwagi, mimo że oboje zawładnęli obszarami, które niegdyś należały do Cesarstwa, czyli powinny wrócić w jego granice w myśl umów zawartych przez Aleksego I z krzyżowcami ${ }^{8}$. Edessa, zdobyta przez Seldżuków w 1087 r., a w 1094 r. przejęta przez Ormianina Torosa, w XI w. była bowiem jednym $z$ najważniejszych miast na wschodnich rubieżach Bizancjum. Ponadto Opowieść o wizerunku z Edessy o powstaniu i translacji mandylionu do Konstantynopola w 944 r. odgrywała istotna rolę w Kościele wschodnim oraz w cesarskiej ideologii dynastii macedońskiej ${ }^{9}$. Niemniej jednak Porfirogenetka prezentuje punkt widzenia, według którego jednym $z$ głównych priorytetów bizantyńskiej polityki wschodniej w połowie XII w. było odzyskanie Antiochii, a nie Edessy, mimo jej znaczacych konotacji.

Baldwin I na kartach Aleksjady pojawia się w czterech narracjach. W pierwszej $z$ nich upomina jednego $z$ uczestników krucjaty, który śmiał usiąść na tronie bizantyńskiego władcy: „Kiedy już wszyscy przybyli wraz z samym Gotfrydem, każdy z nich złożył przysięgę. Jakiś znaczny Łacinnik miał czelność usiąść na tronie cesarskim. Cesarz zniósł to cierpliwie, nie wyrzekł ani słowa, gdyż od dawna znał bezczelny charakter Łacinników. Dopiero hrabia Baldwin podszedł, wziął tego człowieka za rękę, kazał mu wstać i powiedział, mocno ganiąc: "Nie wypada, żebyś tak postępował, przecież obiecałeś służyć cesarzowi. Zwyczaj panujacy u cesarzy rzymskich również nie pozwala poddanym zasiadać wespół z cesarzem. Ci, którzy zostali wasalami jego cesarskiej mości, powinni przestrzegać również obyczajów jego kraju». Ten nie odpowiedział Baldwinowi nic, rzucił strasznym wzrokiem na cesarza i mrukną do siebie kilka słów w ojczystym języku: „Patrz, co za wieśniak, sam siedzi, podczas gdy inni wodzowie stoją"10.

7 Najnowsze opracowania nt. Boemunda por. J. Flori, Bohémond d'Antioche: Chevalier d'aventure, Paris 2007; L. Ru s s o, Boemondo. Figlio di Guiscardo e principe di Antiochia, Avellino 2009; G. The ot ok is, Bohemond of Taranto: Crusader and Conqueror, Barnsley 2020.

${ }^{8}$ Por. J. Pryor, The oaths of the leaders of the First Crusade to Emperor Alex-

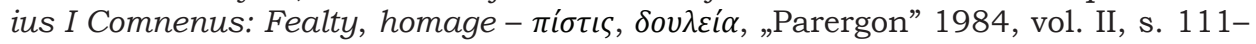
141; J. Shepard, When Greek meets Greek: Alexius Comnenus and Bohemond in 1097-98, „Byzantine and Modern Greek Studies” 1988, vol. XII, s. 185-278.

${ }^{9}$ Por. M. Ty c ner-Wolicka, Opowieść o wizerunku z Edessy. Cesarz Konstantyn Porfirogeneta i nieuczyniony ręka wizerunek Chrystusa, Kraków 2009.

10 Przekł. za: Aleksjada, X, 10, 6, s. 432; tekst oryginalny: Alexias, X, 10, 6, s. 316; w tekście wykorzystuję tłumaczenie O. Jurewicza $z$ naniesionymi poprawkami. 
W przywołanej narracji Baldwin z Boulogne jawi się jako postać znajaca obyczaje panujace w Konstantynopolu oraz przywołująca do porzadku stereotypowo wyniosłego i pysznego anonimowego Franka ${ }^{11}$. Ze słów, które Porfirogenetka włożyła w usta przyszłego króla Jerozolimy, wynika, że darzy on szacunkiem cesarza, jako tego, komu obiecał służyć, oraz gotowy jest uszanować nie tylko postanowienia złożonej przysięgi, lecz także reguły dyplomatyczne, obyczaje i bizantyński ceremoniał dworski. Ponadto trudno nie odnieść wrażenia, że Baldwin spełnia określona funkcję w narracji. Wcześniej bowiem nie pojawia się przy żadnej okazji, czy to w przypadku opisu przemarszu hufca lotaryńskiego, czy też składania hołdu cesarzowi przez dowódców frankijskich, a więc w czasie, w którym według źródeł łacińskich odgrywał on już pewną rolę $u$ boku swoich braci, Gotfryda $z$ Bouillon i Eustachego $z$ Bou$\operatorname{logne}{ }^{12}$. Mając jednak na uwadze, że Anna opisywała wydarzenia po około półwieczu, należy podkreślić, że mogła na niego patrzeć przez pryzmat jego późniejszego znaczenia politycznego. Od razu bowiem

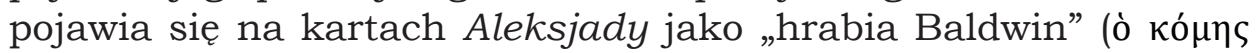
B $\alpha \lambda \delta$ ovĩvo $)^{13}$, aczkolwiek raczej trudno oczekiwać, żeby Komnena znała aż na tyle skomplikowane realia polityczne terenów lotaryńskich, aby wiedzieć, że przez krótki okres 1095 r. zarządzał on hrabstwem Verdun ${ }^{14}$. Wydaje się zatem, że Anna z pamięci nazywa

${ }^{11}$ Por. R.-J. Lilie, Anna Komnene und die Lateiner, „Byzantinoslavica” 1993, t. LIV, s. 169-182; A. Kazhdan, Latins and Franks in Byzantium: Perception and Reality from the Eleventh to the Twelfth Century, [w:] The Crusades from the Perspective of Byzantium and the Muslim World, eds A. Laiou, R.P. Mottahedeh, Washington, D.C. 2001, s. 83-100; T. Pełech, op. cit., s. 182-193.

12 Gesta Francorum et aliorum Hierosolimitanorum, ed. H. Hagenmeyer, Heidelberg 1890, II, 1, s. 107, III, 5, s. 142; Piotr Tudebod, Historia de Hierosolymitano Itinere, eds J.H. Hill, L.L. Hill, Paris 1977, s. 33, 38-39; Le "Liber" de Raymond d'Aguilers, eds J.H. Hill, L.L. Hill, Paris 1969 [dalej: RA], s. 92; A1bert of Aachen, Historia Ierosolimitana, History of the Journey to Jerusalem, ed. and transl. S.B. Edgington, Oxford 2007 [dalej: AA], II, 1, s. 60; II, 4, s. 66; II, 5, s. 68 ; II, 6, s. 70; II, 10, s. 74, 76; II, 13, s. 78, 80. O roli i znaczeniu Baldwina w hufcu lotaryńskim Gotfryda z Bouillon por. A.V. Murray, op. cit., s. 46-62; idem, The Army of Godfrey of Bouillon, 1096-1099: Structure and Dynamics of a Contingent on the First Crusade, "Revue belge de philologie et d'histoire" 1992, t. LXX, no. 2, s. 301-329. Na temat uczestnictwa w I krucjacie Eustachego III z Boulogne por. H.J. Ta n n e r, In his Brothers' Shadow: The Crusading Career and Reputation of Eustace III of Boulogne, [w:] The Crusades: Other Experiences, Alternate Perspectives, ed. K.I. Semann, Binghamton 2003, s. 83-99.

${ }_{13}$ Alexias, X, 10, 6, s. 316.

${ }^{14}$ Baldwin I był właściwie zarządca hrabstwa Verdun przez bardzo krótki czas. Rzeczywistym władca był bowiem biskup Richer, któremu Gotfryd z Bouillon 
go hrabią w odniesieniu do zdobytej później Edessy, której był pierwszym łacińskim władcą ${ }^{15}$. Być może też tytuł ten odnosi się do wysokiej pozycji Baldwina w wojskach krzyżowców, bez wskazania na określone terytorium. Podobnie jak wspomnienie o 300 „hrabiach", których Aleksy I uwolnił z fatymidzkiej niewoli ${ }^{16}$. W każdym razie tytulatura "hrabia Baldwin” wyróżnia go na tle wielu innych przedstawionych w utworze Franków. Podkreślenie jego statusu mogło być więc celowym zabiegiem narracyjnym. $Z$ jednej strony miało to unaocznić brak ogłady anonimowego rycerza, potępionego przez wyższego mu ranga współtowarzysza, któremu nie ważył się nawet odpowiedzieć. $Z$ drugiej zaś Baldwin mógł być idealna postacia do odegrania wskazanej roli w Aleksjadzie, jako ktoś znacznie bardziej rozpoznawalny na bizantyńskim dworze, demonstrując właściwy, albo raczej pożądany wzorzec postępowania krzyżowców względem majestatu Bizancjum.

Aczkolwiek w całości narracji najważniejsza jest rola głównego bohatera, czyli Aleksego I, który mimo cierpkich słów rzuconych przez anonimowego Franka, nie tylko go nie zganił, ale jeszcze dał mu wskazówki, jak należy właściwie walczyć z Turkami. Oczywiście krnąbrny krzyżowiec nie usłuchał rad i wkrótce w starciu $z$ wrogiem został ciężko ranny. Dopiero wtedy uświadomił sobie, że powinien zastosować się do porad Aleksego $\mathrm{I}^{17}$. W ten sposób niejako został ukarany na kartach Aleksjady. We wskazanej narracji Baldwin odegrał więc epizodyczna, drugoplanową rolę, w której wywyższony ponad krnąbrnego krzyżowca został przede wszystkim bizantyński cesarz.

Komnena wzmiankuje również Baldwina przy okazji opisu dalszych losów Franków po sukcesie I wyprawy krzyżowej. Przedstawia zwycięstwo krzyżowców nad wojskami wezyra al-Afdala niemal

sprzedał liczne ziemie wraz $z$ Verdun w celu pozyskania funduszy na wyprawę do Ziemi Świętej. Richer przekazał co prawda Baldwinowi hrabstwo, albo raczej urząd hrabiowski, ale ten wkrótce także wyruszył na Wschód i pozostawił ziemie w rękach biskupa. Por. A.V. Murray, The Crusader Kingdom of Jerusalem..., s. 35.

15 Na temat Hrabstwa Edessy por. M. A m ou roux-M ou rad, Le Comté d'Édesse (1098-1150), Paris 1988; S. Ferdinandi, La Contea Franca di Edessa. Fondazione e Profilo Storico del Primo Principato Crociato nel Levante (1098-1150), Rome 2017.

16 Alexias, XI, 7, 3, s. 343.

17 Alexias, X, 10, 6, s. 316-317; XI, 3, 4, s. 330-331. O polityce Aleksego I względem krzyżowców por. J. She pard, „Father" or „scorpion”? Style and substance in Alexios's diplomacy, [w:] Alexios I Komnenos: Papers of the second Belfast Byzantine International Colloquium, 14-16 April 1989, eds M. Mullet, D. Smythe, Belfast 1996, s. 68-132. 
od razu po zdobyciu Jerozolimy, a następnie klęskę, która według autorki miała nastapić już kolejnego dnia: „Nazajutrz jednak napadła na Łacinników $z$ tyłu przednia straż wroga. Klęskę ponieśli Łacinnicy, ratując się ucieczką do Ar-Ramla. Wśród nich nie było hrabiego Baldwina. Uciekł jeszcze przedtem nie tyle $z$ tchórzostwa, ile ze względu na dużo większą troskę o ocalenie wojska potrzebnego potem do walki z Babilończykami"18.

Niemniej jednak Anna Komnena wskazuje na ostateczne zwycięstwo Franków: „Wzmiankowany powyżej Baldwin objechał wszystkie pomniejsze twierdze zdobyte przez Franków. Zebrał w nich niemałe oddziały jazdy i piechoty. Sformował potężne wojsko, napadł na Babilończyków i zadał im całkowitą klęskę"19.

Wizja zdarzeń Porfirogenetki przypomina chaotyczną próbę połączenia informacji o zmaganiach krzyżowców $z$ al-Afdalem w latach 1099-1102 (lub też 1105) ${ }^{20}$. Można się domyślać, że ze źródeł albo od swoich informatorów Anna dowiedziała się o bitwie pod Askalonem z 1099 r., a także o dwóch lub trzech starciach pod Ar-Ramlą w latach 1101, 1102 i 1105 . Niemniej wydarzenia te rozgrywały się pół wieku przed powstaniem Aleksjady, tak więc ulotna pamięć bądź niedokładna znajomość rzeczy mogły mieć wpływ na ostateczny kształt narracji. Najwyraźniej doszło do kontaminacji wszystkich starć, łącznie trzech albo czterech bitew, w jedna kampanię zakończona sukcesem Franków. Ponadto o nieprecyzyjności opisu Anny świadczy także dalsza narracja, gdzie cesarz, na wieść o klęsce krzyżowców w jednej z bitew, postanowił wykupić pewną liczbę znacznych spośród nich (tytułowanych „hrabiami”) $z$ fatymidzkiej niewoli: „Amerymnes [al-Afdal - przyp. T.P.] przeczytał list autokratora. Ochoczo, nie sprzeciwiając się, wypuścił $z$ niewoli hrabiów bez okupu, $z$ wyjątkiem Gotfryda. Tego już przedtem wydał za okupem jego bratu Baldwinowi. Hrabiowie przybyli do stolicy, gdzie cesarz przyjął ich $z$ honorami, obdarował dużymi pieniędzmi,

${ }_{18}$ Aleksjada, XI, 7, 2, s. 470; Alexias, XI, 7, 2, s. 342-343.

${ }_{19}$ Aleksjada, XI, 7, 2, s. 470; Alexias, XI, 7, 2, s. 343.

20 O starciach pod Ar-Ramla w latach 1101, 1102 i 1105 por. M. Brett, The Battles of Ramla (1099-1105), [w:] Egypt and Syria in the Fatimid, Ayyubid and Mamluk Eras. Proceedings of the $1^{\text {st }}, 2^{\text {nd }}$, and $3^{\text {rd }}$ international colloquium organized at the Katholieke Universiteit Leuven in May 1992, 1993, and 1994, eds U. Vermeulen, D. De Smet, K. d'Hulster, Leuven 1995, s. 17-39; S. Tibble, Crusader Armies: 1099-1187, New Haven-London 2018, s. 211-251; S.B. Edgington, op. cit., s. $129-150$. 
a kiedy dobrze wypoczęli, odesłał zadowolonych do domu. Gotfryd natomiast znowu został królem Jerozolimy. Brata swego, Baldwina, wysłał do Edessy"21.

W tym miejscu Anna nie dokonuje kontaminacji wydarzeń, ale błądzi, gdyż list Aleksego I do al-Afdala, datowany przez F. Dölgera po 25 maja 1102 r. $^{22}$, nie mógł dotyczyć Gotfryda $z$ Bouillon, gdyż ten zmarł 18 lipca 1100 r. i nie brał udziału w żadnej z bitew pod Ar-Ramlą ${ }^{23}$. Ponadto żadne inne źródła nie wspominają o jego niewoli ani o uwolnieniu go przez Baldwina, majacego jeszcze po starciach $z$ Fatymidami w Palestynie powrócić do Edessy. Na dodatek Anna nazywa Gotfryda „królem Jerozolimy”, czyli tytułem, którego nigdy nie nosił, a używanym dopiero przez jego młodszego brata od grudnia $1100 \mathrm{r}^{24}$

W przytoczonych narracjach trudno o bardziej szczegółową ocenę postaci Baldwina I. Należy jednak zauważyć, że Komnena przedstawia go jako dowódcę wojsk frankijskich, który co prawda nie zawsze jest zwycięski, ale potrafi wykazać szersza myśl strategiczna. Nie pierzcha bowiem $z$ pola przegranej już bitwy $z$ powodu tchórzostwa, ale potrafi ocenić ryzyko i zdaje sobie sprawę, że mimo chwilowej goryczy porażki będzie w stanie w przyszłości zebrać nową armię i ostatecznie pokonać przeciwnika, co też mu się udaje. Wskazany wzorzec właściwego postępowania dowódcy pojawia się w Aleksjadzie w opisie przegranej przez Bizancjum bitwy z Pieczyngami pod Dorostolon (Dristra) w 1087 r. ${ }^{25}$ Protostrator Michał Dukas, brat cesarzowej Ireny, w obliczu zupełnej klęski wygłasza mowę, w której przekonuje Aleksego I, że walczyć mężnie za cenę

${ }^{21}$ Aleksjada, XI, 7, 3, s. 471; Alexias, XI, 7, 3, s. 343.

${ }^{22}$ F. Dölger, Regesten der Kaiserurkunden des oströmischen Reiches, Bd. II (Regesten von 1025-1204), Berlin-München 1925 [bearbeitet von Peter Wirth, München 1995, dalej: Regesten], Nr. 1216, s. 155.

${ }^{23}$ Fulcheri Carnotensis Historia Hierosolymitana (1095-1127), ed. H. Hagenmeyer, Heidelberg 1913, I, XXVI, 1, s. 349-350; H. Ha g e n m e y e r, Chronologie de la première croisade (1094-1100), Paris 1902 [dalej: Chronologie], s. 300-302.

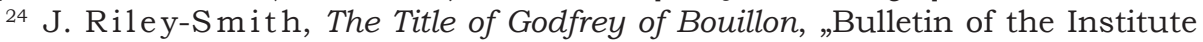
of Historical Research" 1979, vol. LII, No. 125, s. 83-86; J. France, The Election and Title of Godfrey de Bouillon, "Canadian Journal of History” 1983, vol. XVIII, No. 3, s. 321-329; A.V. Murray, The Title of Godfrey of Bouillon as Ruler of Jerusalem, „Collegium Medievale” 1990, vol. III, s. 163-167.

${ }^{25} \mathrm{Na}$ temat zmagań Bizancjum z Pieczyngami por. P. Stephenson, Byzantium's Balkan Frontier: A political Study of the Northern Balkans, 900-1204, Cambridge 2000, s. 80-116. 
życia może „ktoś zwyczajny” (ò koเvós), natomiast władca powinien się uratować, aby w przyszłości móc odnieść zwycięstwo ${ }^{26}$. Podobnie po przegranych bitwach $z$ Boemundem pod Joannina oraz Arta cesarz ratuje się, żeby móc znów stawić czoła wrogowi, a Porfirogenetka nie postrzega tego jako czynu niegodnego ${ }^{27}$. W swoim postępowaniu Baldwin I przypomina więc Aleksego I z kart Aleksjady, ponoszacego poczatkowo szereg porażek, tuszowanych sprytnymi zabiegami retorycznymi przez Annę Komnenę ${ }^{28}$, ale ostatecznie wychodzącego zwycięsko $z$ większości prowadzonych kampanii wojennych, np. $z$ Normanami (w latach 1081-1085 i 1107-1108) czy z Pieczyngami (1086-1091) ${ }^{29}$. Zbieżność nie wydaje się zatem przypadkowa, ponieważ pochwała zdolności bojowych Baldwina $z$ Boulogne wpisuje się $\mathrm{w}$ szerszy kontekst przedstawiania Łacinników w literaturze bizantyńskiej ${ }^{30}$. Ponadto można zauważyć, że przyszły władca Jerozolimy w Aleksjadzie, mimo nieprawdziwości przytoczonych informacji, jawi się jako swoisty obrońca Franków pod nieobecność przebywającego w niewoli Gotfryda. Baldwin I staje na czele krzyżowców w zwycięskiej konfrontacji z Fatymida$\mathrm{mi}$, on też wykupuje brata $\mathrm{z}$ rak al-Afdala, a następnie oddaje mu władzę i wraca do Edessy.

Anna Komnena zwraca następnie uwagę na Baldwina w krótkim opisie wyboru nowego króla Jerozolimy: „Po śmierci Gotfryda trzeba było wybrać na jego miejsce innego króla. Łacinnicy przebywajacy w Jerozolimie niezwłocznie wezwali Isangelesa [Rajmunda z Saint-Gilles - przyp. T.P.] z Trypolisu, gdyż chcieli obwołać go

\footnotetext{
26 Alexias, VII, 3, 10, s. 213; Aleksjada, VII, 3, 10, s. 296.

27 Alexias, V, 4, 3, s. 150; V, 4, 7, s. 152; Aleksjada, V, 4, 3, s. 204; V, 4, 7, s. 206.

${ }^{28}$ P. Buckley, op. cit., passim; L. Neville, op. cit., s. 43-60.

29 Por. W.B. McQueen, Relations between the Normans and Byzantium, 1071-1112, „Byzantion” 1986, vol. LVI, s. 427-476; M. Mesko, Boje Byzancie s Pecenehmi o Trakiu v rokoch 1088 az 1091, „Vojenska Historia” 2007, t. I, s. 3-27.

30 Szerzej na temat obrazu Łacinników w Bizancjum por. J. Hermans, The Byzantine View of the Normans - Another Norman Myth?, "Anglo-Norman Studies" 1979, vol. II, s. 78-92; G.A. Loud, Anna Komnena and her Sources for the Normans of Southern Italy, [w:] Church and Chronicle in the Middle Ages. Essays Presented to John Taylor, eds G.A. Loud, I.N. Wood, London 1991, s. 41-57; E. A1bu, Bohemond and the Rooster: Byzantines, Normans, and the Artful Ruse, [w:] Anna Komnene and Her Times, s. 157-168; T. Pełech, op. cit., passim; S. Wierzbińs ki, Szlachetni, odważni, dzicy? Obraz Waregów i Franków w oczach Bizantyńczyków w X-XI w., „Vox Patrum” 2018, R. CXIX, s. 647-679.
} 
królem Jerozolimy. Isangeles wciąż odkładał swój wyjazd. Kiedy pojechał do stolicy, mieszkańcy Jerozolimy zrozumieli, że zwleka. Posłali więc Baldwina przebywającego wówczas w Edessie i ustanowili go królem Jerozolimy. Cesarz przyjął Isangelesa $z$ radością. Na wiadomość, że władzę nad Jerozolimą przejął Baldwin, zatrzymał u siebie Isangelesa, dopóki nie przybyły wojska Normanów pod dowództwem dwóch braci zwanych Blandratami"31.

W przytoczonej narracji podkreślona jest przede wszystkim rola Isangelesa, czyli hrabiego Tuluzy Rajmunda $z$ Saint-Gilles, przedstawionego w Aleksjadzie jako wiernego cesarzowi i najlepszego spośród Franków ${ }^{32}$. Jednakże żadne inne źródła nie wspominaja, żeby był on kandydatem na jerozolimski tron po smierci Gotfryda $z$ Bouillon w lipcu 1100 r. Wiadomo natomiast, że ubiegał się o władzę w roku 1099, po zdobyciu Świętego Miasta przez wojska I krucjaty, aczkolwiek ostatecznie nie przyją ofiarowanej mu korony $^{33}$. W lipcu 1100 r. Rajmund z Saint-Gilles nie rywalizował

${ }^{31}$ Aleksjada, XI, 8, 1, s. 474-475; Alexias, XI, 8, 1, s. 346.

${ }^{32}$ Zupełnie inny obraz przekazują źródła łacińskie, w tym Rajmund z Aguilers, kapelan Rajmunda $z$ Saint-Gilles, który wręcz $z$ wrogością prezentuje postawę hufca prowansalskiego w stosunku do Bizancjum, a samego Aleksego I jako złego, przewrotnego i szkodzącego Frankom (np.: RA, s. 38: „venimus Dirachium, credimus esse in patria nostra, existimantes imperatorem Alexium et satellites suos nobis esse fratres, et coadiutores. Illi vero ritu leonum incrudescentes, pacificos homines nichil [sic!] minus quam arma cogitantes, invadunt per occulta trucidant, in nemoribus in vicis remotis a castris, quae poterant per noctem furabantur” - „Przybyliśmy do Dyrrachium, wierząc, że jesteśmy w naszej ojczyźnie, sądząc, że cesarz Aleksy i jego wasale są nam braćmi i pomocnikami. Oni napadali na ludzi, którzy byli nastawieni pokojowo i nie myśleli w ogóle o walce, w lasach w ukryciu napadali, a we wsiach oddalonych od zamków, co mogli, rabowali (przekł. autor)". Na dodatek hrabia Tuluzy miał złożyć cesarzowi hołd jako ostatni z przywódców I krucjaty i w odmiennej od wszystkich formie, por. RA, s. 41-42; J.H. Hi11, L.L. Hi11, The Convention of Alexius Comnenus and Raymond of Saint Gilles, „The American Historical Review” 1953, vol. CVIII, No. 2, s. 322-327.

${ }^{33}$ Por. L. Ferrier, La couronne refusée de Godefroy de Bouillon: eschatologie et humiliation de la majesté au premier temps du royaume latin de Jérusalem, [w:] Le concile de Clermont de 1095 et l'appel à la croisade. Actes du Colloque Universitaire International de Clermont-Ferrand (23-25 juin 1995), Rome 1997, s. 245-265; A.V. Murray, Daimbert of Pisa, the Domus Godefridi and the Accession of Baldwin I of Jerusalem, [w:] Clermont to Jerusalem: The Crusades and Crusader Societies 1095-1500, ed. A.V. Murray, Turnhout 1998, s. 81-102; ide m, The Crusader Kingdom of Jerusalem..., s. 63-77, 94-96; J. Rubenstein, Godfrey of Bouillon Versus Raymond of Saint-Gilles: How Carolingian Kingship Trumped Millenarianism at the End of the First Crusade, [w:] The Legend of Charlemagne in the Middle Ages, eds M. Gabriele, J. Stuckey, New York 2008, s. 59-75. 
o Jerozolimę $z$ Baldwinem, ale był w drodze $z$ Laodycei do Konstantynopola ${ }^{34}$. Trypolis natomiast wciąż znajdował się w rękach Fakhr al-Mulka $z$ rodu Banu Ammar ${ }^{35}$. Znów więc Anna przeniosła przyszłe wydarzenia i własne wyobrażenia na wcześniejsze realia polityczne. W tym kontekście można również rozpatrywać postawienie w narracji Rajmunda $z$ Saint-Gilles, mającego być pierwszym kandydatem na króla Jerozolimy, niejako przed Baldwinem, po którego posłano do Edessy dopiero, gdy hrabia Tuluzy się wahał. Baldwin musi więc w dziele Anny ustapić miejsca najbardziej prawemu spośród Łacinników.

Następne pojawienie się króla Jerozolimy w utworze ma miejsce w związku ze zmaganiami Bizancjum z Normanami. W Aleksjadzie istotna rolę $\mathrm{w}$ cesarskiej polityce odgrywa próba egzekucji postanowień traktatu znad rzeki Devol i zmuszenia do posłuszeństwa Tankreda, regenta Antiochii ${ }^{36}$. Aleksy I po pokonaniu Boemunda w kampanii epirskiej (1107-1108) próbował odzyskać kontrolę nad Cylicją i Księstwem Antiochii, jednakże spotkał się $z$ silnym oporem Normanów, którzy nie wyrazili chęci podporządkowania się Bizancjum $^{37}$. Aleksy I mimo słania poselstw nie był w stanie środkami dyplomatycznymi zmusić Tankreda do uległości, postanowił więc zbrojnie zająć Antiochię. Spotkał się jednak $z$ oporem kół wojskowych i senatorskich, które odradzały natychmiastowa i bezpośrednia akcję militarna. Niemniej doradzono cesarzowi, aby pozyskał dla swojej sprawy władców sąsiadujących z Normanami antiocheńskimi, w tym króla Jerozolimy Baldwina $\mathrm{I}^{38}$. W tym celu wysłano poselstwo, w skład którego wchodził Manuel Butumita ${ }^{39}$, mające wybadać stosunek innych Franków do Tankreda i przekonać ich do bizantyńskiej sprawy za pomoca bogatych podarunków

34 FC, I, XXXII, 1, s. 320; Chronologie, s. 288.

35 Trypolis został zdobyty dopiero przez następcę Rajmunda, Bertranda, w 1109 r. Por. np. FC, II, XLI, 1-4, s. 531-533; AA, XI, 13-15, s. 782-786; The Damascus Chronicle of the Crusades. Extracted and Translated from the Chronicle of Ibn Al-Qalanisi, ed. H.A.R. Gibb, New York 1932 [przedruk 2014, dalej: Al-Qalanisi].

36 O traktacie por. Alexias, XIII, 12, 1-28, s. 413-423; Regesten, No. 1243, s. $166-167$.

${ }^{37} \mathrm{Na}$ temat kampanii Boemunda w Epirze por. G. Rösch, Der „Kreuzzug” Bohemundus gegen Dyrrachion 1107/1108 in der leteinischen Tradition des 12. Jahrhunderts, „Römische Historische Mitteilungen” 1984, Bd. XXVI, s. 181-190.

${ }^{38}$ Alexias, XIV, 2, 1-5, s. 427-429.

${ }^{39}$ Alexias, XIV, 2, 6, s. 429-430; A. Kazhdan, Boutoumites, [w:] The Oxford Dictionary of Byzantium, ed. A. Kazhdan, Oxford-New York 1991, vol. I, s. 318-319. 
oraz dużej sumy pieniędzy, gdyż jak podsumowała Anna: „Łacinnicy lubują się w chciwości" 40 .

Ta myśl, prezentująca jedną $z$ dominujacych cech $\mathrm{w}$ bizantyńskim obrazie Łacinników, jest widoczna w opisie postępowania Baldwina I od momentu przybycia cesarskich wysłanników do Trypolisu. Król Jerozolimy był bowiem „ogarnięty żądzą pieniędzy” ${ }^{4}$. Mimo że przyjął bizantyńskich posłów w swoim obozie w czasie oblężenia Tyru „z radością i uprzedzająco grzecznie”, a nawet zatrzymał ich na cały okres wielkiego postu, to na koniec wizyty zażądał cesarskich pieniędzy, nim ujawnił swoje stanowisko w sprawie Tankre$\mathrm{da}^{42}$. Na taki przebieg wypadków zareagował Manuel Butumita: „Wówczas dopiero otrzymacie przeznaczone wam pieniądze, kiedy przyobiecacie autokratorowi swa pomoc przeciwko Tankredowi, dotrzymując tym samym przysięgi, jaką mu złożyliście"43. Jednakże Baldwin I nie zamierzał atakować Antiochii w myśl interesów bizantyńskich, ale pragnął otrzymać pieniądze, których, jako królowi Jerozolimy, zawsze mu brakowało ${ }^{44}$. Jak zaznacza Anna: „Martwił się, że nie otrzymał tych pieniędzy. Taki to już jest zwyczaj tego plemienia barbarzyńskiego; $z$ otwartymi ustami staja na widok darów i pieniędzy, lecz wcale nie kwapią się do zrobienia tego, za co daje im się te pieniądze. Baldwin wręczył więc Butumicie zwykły list i rozstał się $z$ nim" ${ }^{45}$. Bizantyńskie poselstwo zakończyło się ostatecznie fiaskiem, gdyż nie udało się pozyskać nikogo spośród Franków do wspólnej akcji przeciwko Tankredowi. Autorka Aleksjady sugeruje nawet, że król Jerozolimy chciał przyjść $z$ pomoca nie cesarzowi, ale Normanom antiocheńskim ${ }^{46}$. Potwierdzeniem braku chęci występowania Franków przeciwko sobie była rozmowa posłów Aleksego I z Joscelinem de Courtenay, który miał prezentować to samo stanowisko co Baldwin I, a także zmiana władcy w Hrabstwie Trypolisu, gdzie wkrótce przyjaznego Bizancjum Bertranda zastapił Pons, sympatyzujacy z Tankredem ${ }^{47}$.

40 Aleksjada, XIV, 2, 6, s. 600; Alexias, XIV, 2, 6, s. 430; o poselstwie wzmiankuje również Albert z Akwizgranu, który twierdzi, że Bizantyńczycy otrzymali wspaniałe dary: AA, XII, 8, s. 834.

${ }^{41}$ Aleksjada, XIV, 2, 8, s. 601; Alexias, XIV, 2, 8, s. 431.

${ }^{42}$ Aleksjada, XIV, 2, 8, s. 602; Alexias, XIV, 2, 8, s. 431.

43 Aleksjada, XIV, 2, 13, s. 604-605; Alexias, XIV, 2, 13, s. 433.

${ }^{44}$ S. Runciman, op. cit., s. 68-99.

45 Aleksjada, XIV, 2, 13, s. 605; Alexias, XIV, 2, 13, s. 433.

46 Alexias, XIV, 2, 13, s. 433.

${ }^{47}$ Alexias, XIV, 2, 13-14, s. 433-434. 
Nic zatem dziwnego, że Anna w tym przypadku obdarzyła pośrednio Baldwina I mianem barbarzyńcy (a nieco dalej już bezpośrednio), czyli słowem będącym „kwintesencją kulturalnej odrębności", wykorzystywanym przez Porfirogenetkę w szczególności w odniesieniu do postaci, które występuja przeciwko interesom Cesarstwa Bizantyńskiego ${ }^{48}$.

Przy okazji poselstwa przedstawionego w Aleksjadzie Baldwin I okazuje się także osoba niezwykle dobrze poinformowana o poczynaniach Aleksego I, przez co udaje mu się nie wpaść w sidła bizantyńskiej intrygi. Po oblężeniu Tyru Manuel Butumita udał się do siedziby króla w Akce, aby przekazać ostatecznie, co polecił mu cesarz, dodajacc, jako pewien środek nacisku mający „przestraszyć barbarzyńcę", że Aleksy I prowadzi kampanię militarną w Anatolii i znajduje się już w Seleukeii ${ }^{49}$. Niemniej jednak podstęp się nie udał, ponieważ Baldwin I jeszcze w czasie oblężenia Tyru dowiedział się od pewnego uciekiniera $z$ połaczonej floty Pizy, Genui i innych terenów italskich, która pustoszyła tereny bizantyńskie, że cesarz przepędził najeźdźców, a następnie zachorował i udał się do Konstantynopola ${ }^{50}$. Wskutek niezręczności Manuela Butumity relacje Franków z Bizancjum stały się napięte, zwłaszcza że król Jerozolimy miał jeszcze przy każdej okazji nazywać posła kłamcą ${ }^{51}$.

Ostatnim elementem narracji odnoszącym się do Baldwina I, który warto wziąć pod uwage w formułowaniu oceny o nim na kartach Aleksjady, jest prowadzone w czasie trwania poselstwa

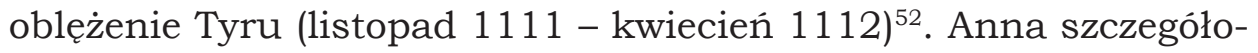
wo rozpisuje się o fortyfikacjach miasta, wzmiankując o trzech pasach umocnień oraz przebiegu zmagań militarnych zakończonych

${ }^{48}$ H. Ahrweiler, Byzantine Concepts of the Foreigner: The case of the Nomads, [w:] Studies on the Internal Diaspora of the Byzantine Empire, ed. H. Ahrweiler, A. Laiou, Dumbarton Oaks 1998, s. 11; por. także K. Le ch ner, Hellenen und Barbaren im Weltbild der Byzantiner, München 1955; T. Peł e ch, op. cit., passim.

49 Aleksjada, XIV, 2, 12, s. 604; Alexias, XIV, 2, 12, s. 432-433.

50 Alexias, XIV, 3, 4, s. 436.

${ }^{51}$ Alexias, XIV, 2, 12, s. 433. Co warto podkreślić, w tym miejscu w Aleksjadzie pojawia się druga wypowiedź w mowie niezależnej autorstwa Baldwina I (pierwsza Alexias, X, 10, 6, s. 316). Skierowana jest do Manuela Butumity, któremu król przekazal, że ten musi wraz z nim udać się do Jerozolimy i tam oczekiwać na ostateczną odpowiedź.

52 Alexias, XIV, 2, 8-11, s. 431-432; FC, II, XLVI, 1-4, s. 558-562; AA, XII, 3-7, s. 826-834; Al-Qalanisi, s. 119-126; por. S. Edgington, op. cit., s. 106, 162. 
niepowodzeniem krzyżowców ${ }^{53}$. Sugeruje to, że mogła czerpać informacje bezpośrednio od członków poselstwa, którzy przebywali $z$ Baldwinem I pod Tyrem, bądź osób dobrze obeznanych $z$ tymi wydarzeniami ${ }^{54}$. Według Porfirogenetki w początkowej fazie oblężenia Frankowie zdobyli dwie $z$ trzech linii umocnień za pomoca maszyn oblężniczych. Następnie Baldwin I przystapił do zdobywania ostatnich punktów oporu miasta. Jednakże w kluczowej chwili, zamiast energicznie kontynuować natarcie, oddał się wypoczynkowi, sądząc, że zdobędzie Tyr za pomoca samych tylko drabin, a zwycięstwo jest już na wyciagnięcie ręki ${ }^{55}$. Anna przedstawia, jak początkowe sukcesy zostały zmarnotrawione, gdyż obrońcy miasta, wykorzystując bierność Franków, wysłali posłów pod pozorem omówienia warunków poddania się. W tym samym czasie zniszczyli maszyny oblężnicze krzyżowców, obrzucając je glinianymi amforami wypełnionymi płynną smoła, a następnie podpalając je, co doprowadziło do ogromnego pożaru ${ }^{56}$. Podczas wypadu pojmano również sześciu żołnierzy Baldwina I, a dowódca obrony Tyru kazał odciać im głowy i wystrzelić w stronę Franków ${ }^{57}$. Jak relacjonuje Anna, na widok ognia i głów krzyżowcy rzucili się do panicznej ucieczki w stronę Akki, a król w żaden sposób nie mógł ich zawrócić. Według Aleksjady: „Baldwin wpadł w rozpacz. Zupełnie bezsilny popędził, chociaż wbrew woli, za uciekającymi i skrył się we wspomnianym mieście [Akce - przyp. T.P.]"58.

Szczegółowy opis zdobywania Tyru u Anny Komneny pozwala na dokonanie kilku ustaleń. Można zauważyć wyraźne dwa etapy narracji i oceny postaci króla Jerozolimy. Początkowo Baldwin I odnosi sukcesy, energicznie prowadzac działania wojenne $z$ wykorzystaniem maszyn oblężniczych i zdobywając dzięki temu dwie $z$ trzech linii umocnień Tyru. W podobnym tonie w Aleksjadzie przedstawiony został Boemund podczas nieudanego dlań oblężenia Dyrrachium (listopad 1107 - wrzesień 1108), porównany nawet do

53 Alexias, XIV, 2, 8-11, s. 431-432.

${ }^{54} \mathrm{Na}$ temat źródeł Anny Komneny w zagadnieniach militarnych por. K. Sinclai r, Anna Komnene and her Sources for Military Affairs in the Alexiad, „Estudios bizantinos" 2014, vol. II, s. 143-185.

55 Alexias, XIV, 2, 8-11, s. 431-432.

56 O wypadzie załogi miasta i podpaleniu za pomoca m.in. ognia greckiego maszyn oblężniczych Franków wspomina również arabski kronikarz Ib n al-Q alanisi, por. Al-Qalanisi, s. 122-123.

57 Alexias, XIV, 2, 11 , s. 432.

58 Aleksjada, XIV, 2, 11, s. 604; Alexias, XIV, 2, 11, s. 432. 
Demetriusza Poliorketesa, jako ten, który charakteryzuje się wysoka sprawnościa $\mathrm{w}$ obleganiu miast ${ }^{59}$. Anna potrafi więc docenić sztukę oblężniczą Franków, przypisując pozytywne cechy wojskowe części $z$ nich. Niemniej jednak ostatecznie wojska krzyżowców ponoszą klęskę $z$ rąk przeciwników i uciekają $w$ panice, mimo prób króla, aby je zatrzymać. W związku z porażka pod Tyrem na kartach Aleksjady pada kilka zarzutów pod adresem Baldwina I. Według Anny „Był bliski zwycięstwa, a odsunął je daleko od siebie", wskutek zmarnotrawionego czasu i braku aktywności ${ }^{60}$. Dał się przechytrzyć obrońcom miasta, którzy tylko pozorowali próbę poddania się $e^{61}$. Główny ciężar oskarżeń Komneny padł jednak na wojowników frankijskich, tkwiących w bezczynności i lekkomyślności, za co przyszło im słono zapłacić ${ }^{62}$. Ponadto mimo królewskich zachęt i prób powstrzymania ucieczki, ci: „pędzili niepowstrzymani. Mknęli, wydawało się, szybciej niż na skrzydłach ptaka, czym zasłużyli sobie na miano tchórzliwych biegaczy"63. Warto jednakże zaznaczyć, że Anna nigdy nie oskarża Baldwina I o tchórzostwo, wręcz przeciwnie. Gdy tylko bowiem zauważył on ucieczkę swoich wojsk, to od razu podją się próby ratowania tragicznej sytuacji: „galopujacc na wszystkie strony, przyzywał uciekinierów i dodawał im wszelkimi sposobami odwagi" ${ }^{64}$. Jego wysiłki nie były jednak skuteczne i - jak odnotowała autorka Aleksjady - „śpiewał dla głuchych"65.

Warto wziąć pod uwage możliwość, że na wizję nieudanego oblężenia Tyru przez krzyżowców i na tezę o ich braku aktywności w działaniu w dziele Anny mogło wpłynąć nieudane oblężenie Szajzaru przez Jana II Komnena $z$ kwietnia-maja 1138 r. ${ }^{66} \mathrm{~W}$ syryjskiej kampanii bizantyńskiego cesarza wzięli bowiem udział Łacinnicy: Rajmund I, książę Antiochii (1136-1149), oraz Joscelin II,

${ }^{59}$ Aleksjada, XII, 9, 3, s. 530; Alexias, XII, 9, 3, s. 382; por. T. Pełech, op. cit., s. $157-158$.

60 Aleksjada, XIV, 2, 9, s. 602; Alexias, XIV, 2, 9, s. 431.

61 Alexias, XIV, 2, 10, s. 432.

62 Alexias, XIV, 2, 11, s. 432.

${ }^{63}$ Aleksjada, XIV, 2, 11, s. 603-604; Alexias, XIV, 2, 11, s. 432.

${ }^{64}$ Aleksjada, XIV, 2, 11, s. 603; Alexias, XIV, 2, 11, s. 432.

65 Aleksjada, XIV, 2, 11, s. 603; Alexias, XIV, 2, 11, s. 432.

66 Najnowsze przedstawienie kampanii syryjskiej Jana II Komnena i jej znaczenia, por. A. Papageorgiou, The political ideology of John II Komnenos, [w:] John II Komnenos, Emperor of Byzantium: In the Shadow of Father and Son, ed. A. Bucosssi, A.R. Suarez, Abingdon-New York 2016, s. 43-45; M.M. Vučetić, Emperor John Il's encounters with foreign rulers, [w:] ibidem, s. 79-90. 
hrabia Edessy (1131-1149). Podczas gdy Jan II w zgodnej opinii źródeł, zarówno bizantyńskich, łacińskich, jak i arabskich, odznaczał się walecznościa, odwaga i aktywnością w działaniu, to władcy frankijscy wykazali się całkowitym brakiem chęci zaangażowania się w działania militarne. W czasie oblężenia woleli bowiem zostać w swoim obozie, aby grać w kości i ucztować, co negatywnie wpłynęło na morale podległych im wojsk ${ }^{67}$. Mimo początkowych sukcesów, jak zdobycie miasta za wyjątkiem cytadeli, bizantyński cesarz postanowił zawrzeć ugodę $z$ emirem Szajzaru i wycofać swoje siły ${ }^{68}$.

Być może więc, kreśląc obraz oblężenia Tyru, Anna korzystała $z$ obiegowych opinii na temat krzyżowców, inspirując się m.in. oblężeniem z 1138 r. Może za tym przemawiać bliskość w czasie wydarzeń, które mogły być wciąż żywe w bizantyńskich kręgach dworskich, wojskowych i intelektualnych, wtedy gdy powstawała Aleksjada. Zwłaszcza że w wyprawie syryjskiej Jana II $z$ roku 1137, w której zdobyto Cylicję i podporządkowano Cesarstwu frankijska Antiochię oraz przygotowano grunt pod dalsze działania w regionie, brał udział mąż Anny, Nikefor Bryennios ${ }^{69}$. Jego relacje zaś stanowią istotny zasób wiedzy Porfirogenetki i bez watpienia wpłynęły na jej poglądy oraz opinie ${ }^{70}$. Warto również podkreślić,

67 Theodori Prodromi Scripta Miscellanea, [w:] Patrologia Graeca, vol. CXXXIII, ed. J.P. Migne, Paris 1864, col. 1344-1350; Ioannis Cinnami Epitome: Rerum ab Ioannes et Alexio [sic recte Michaele]. Comnenis Gestarum, ed. A. Meineke, Bonnae 1836 [dalej: Cinnami Epitome], I, 8, s. 18-21; Nicetae Choniatae Historia, ed. J.-L. van Dieten, Berolini-Novi Eboraci 1975 [dalej: Choniatae Historia], s. 29; Guillelmi Archiepiscopi Tyrensis Chronicon, ed. R.B.C. Huygens, Turnhout 1986, XV, 1-2, s. 674-676; Al-Qalanisi, s. 248-252; Kamal al-Din, Extraits de la chronique d'Alep, [w:] Recueil des historiens des croisades. Historiens orientaux, t. III, Paris 1884, s. 674-678; An Arab-Syrian Gentleman and Warrior in the period of the Crusades: Memoirs of Usamah ibn-Munqidh (Kitab al-Ptibar), trans1. P.K. Hitti, New York 1929 [przedruk 2000], s. 26, 124, 143-144; Ibn al-Asir, Extrait de la chronique intitulée Kamel-Altevarykh par Ibn-Alatyr, [w:] Recueil des historiens des croisades..., t. I, Paris 1872, s. 426-428.

${ }^{68}$ Ibidem.

69 Alexias, ПРО $\Lambda$ ОГО, , 3, 2, s. 7. L. Neville (op. cit., przyp. 26, s. 183) uważa, że chodzi o kampanię w 1138 r., ale przeczy temu choćby sam przekaz Aleksjady, gdzie wyraźnie jest mowa o kampanii przeciw Antiochii i Cylicji, a także śmierć Nikefora Bryenniosa na przełomie 1136 i 1137 r. W tej kwestii por. P. Gauti er, L'obituaire du typikon du Pantokrator, „Revue des études byzantines” 1969, t. XXVII, no. 1, s. 251-252.

70 W kwestii wpływu Nikefora na pisarstwo Anny Komneny warto wspomnieć o tezie, że znaczna część Aleksjady została napisana przez Bryenniosa (J. Howard-Johnston, Anna Komnene and the Alexiad, [w:] Alexios I Komnenos..., s. 232-302), aczkolwiek nie spotkała się $z$ akceptacją w środowisku naukowym. 
że Nikefor podczas kampanii w Syrii zachorował i wkrótce zmarł, co łączy emocjonalnie Annę ze wskazanymi wydarzeniami i mogło pozostawić trwały ślad w jej pamięci ${ }^{71}$. Ponadto oblężenie Szajzaru wywarło pewien wpływ na postawę Cesarstwa względem Franków i negatywną ocenę ich zachowania ${ }^{72}$. Być może ogólna wizja Łacinników, jako tych, którzy sa silni zwłaszcza w pierwszym ataku, natomiast później brakuje im dyscypliny i odpowiedniej karności, również odegrała swoją rolę ${ }^{73}$. Można także zauważyć zbieżność obu wydarzeń podkreślających, że mimo początkowych sukcesów, wskutek braku aktywności ze strony Franków, na końcu i tak nie udało się zwyciężyć. W tym kontekście opis nieudanego oblężenia Tyru $z$ listopada 1111 - kwietnia 1112 r. stanowi odzwierciedlenie pewnych zbiorowych wyobrażeń na temat Łacinników w Cesarstwie na przełomie pierwszej i drugiej połowy XII w.

W przedstawieniu Baldwina widać, że został pominięty jego wygląd zewnętrzny. Wzmacnia to tezę, że ostatecznie odgrywał on mało istotna rolę w całości dzieła Komneny. Anna bowiem odwołuje się do kanonu portretowania postaci w bizantyńskiej historiografii. Jest to o tyle istotne, że w literaturze greckiej, której dziedzictwo przejęło Bizancjum, według zasad fizjonomiki, na podstawie wyglądu zewnętrznego można było zrozumieć charakter danej jednostki ${ }^{74}$. Stąd też w Aleksjadzie szczególna uwaga jest poświęcona przedstawieniu cech fizycznych głównego bohatera, Aleksego I, a także jego głównych adwersarzy: Roberta Guiscarda oraz Boemunda. Wszystkie wskazane postacie zostały przez Annę ukazane w zgodzie $z$ kanonem urody greckiej, właściwym dla władców, odznaczającym się m.in. harmonijną budową ciała, jasna cerą i wysokim lub średnim wzrostem ${ }^{75}$. Tymczasem w odniesieniu do sylwetki Baldwina I, podobnie jak np. w przypadku Roussela

Por. np. R. Macrides, The Pen and the Sword: Who Wrote the Alexiad?, [w:] Anna Komnene and Her Times..., s. 63-81; D.R. Re in s ch, Women's Literature in Byzantium? The Case of Anna Komnene, [w:] ibidem, s. 83-105; L. N evi1le, Heroes and Romans in Twelfth-Century Byzantium: The "Material for History” of Nikephoros Bryennios, Cambridge 2012, s. 182-193.

71 Alexias, ПРО $\Lambda$ ОГО $, 3,4$, s. 8.

72 Choniatae Historia, s. 39-40.

73 Alexias, XI, 6, 3, s. 339; XI, 8, 1-4, s. 346-347. Por. T. Pełe ch, op. cit., s. 187.

${ }^{74}$ Por. M. Kokoszko, Kanon portretowania $w$ historiografii bizantyńskiej na przykładzie portretu Boemunda w „Aleksjadzie” Anny Komneny, „Acta Universitatis Lodziensis. Folia Historica” 2000, z. 67, s. 59-73.

${ }^{75}$ Por. ibidem, s. 65-67; T. Pełech, op. cit., s. 96-98, 120-123. 
de Bailleul, Porfirogenetka nie zamieściła żadnej wzmianki, wyraźnie dając do zrozumienia, że jest on postacią marginalną.

Podsumowując, warto uwypuklić, że spośród źródeł bizantyńskich tylko w Aleksjadzie pojawia się materiał, który pozwala na dokonanie oceny pierwszego łacińskiego króla Jerozolimy. W świetle przedstawionej analizy należy stwierdzić, że Anna Komnena nie prezentuje go jako pierwszoplanowej postaci swojego dzieła. Baldwin I odgrywa relatywnie skromna i epizodyczna rolę, czego nie zmienia nawet fakt, że w jego usta autorka aż dwukrotnie wkłada mowę niezależną. Zapewne $z$ punktu widzenia Konstantynopola nie był on szczególnie ważnym graczem na scenie politycznej, zarówno w czasie I krucjaty, jak i po wyborze na króla Jerozolimy. Baldwin I pojawia się bowiem szerzej tylko w przypadku narracji o zmaganiach o Antiochię z Tankredem, o która toczyła się główna rozgrywka między Bizancjum a Normanami. Jerozolima zaś leżała znacznie dalej od cesarskich granic i nie była przedmiotem roszczeń terytorialnych. Ponadto warto podkreślić, że znaczna część informacji przekazanych przez Annę na temat Baldwina I ma charakter wybiórczy bądź kontaminacyjny, jak w przypadku walk Franków $z$ al-Afdalem. Porfirogenetka nie opisała również jego cech zewnętrznych. Niemniej jednak z kart Aleksjady wyłania się postać króla o dwóch obliczach. $Z$ jednej strony jest on pożądajacym bogactw „barbarzyńca”, który zamierza wziąć zapłatę za niewykonana pracę, planując postapić wręcz odwrotnie do cesarskich intencji. $Z$ drugiej zaś potrafi uszanować obyczaje panujące w Bizancjum, cieszy się wysokim statusem społecznym wśród Franków od początku narracji, potrafi przechytrzyć przeciwnika, wykazuje się dość szerokimi horyzontami w myśli wojskowej, a także ratuje krzyżowców, pokonując siły Fatymidów i uwalniając $z$ niewoli brata Gotfryda (sic!). Na dodatek swoim zachowaniem na polu bitwy Baldwin I przypomina Aleksego I, a już samo takie zestawienie w dziele Anny było wiele znacząca pochwałą. Kwintesencją ambiwalentności oceny króla Jerozolimy w Aleksjadzie jest oblężenie Tyru. Autorka dzieła nie odmawia mu bowiem odwagi i umiejętności wojskowych, ale zarzuca mu opieszałość, która (choć nie tylko) doprowadza do dotkliwej porażki. Anna Komnena przedstawiła więc Baldwina I w sposób bardzo zbliżony do zbiorowego wyobrażenia Łacinników w Bizancjum. Niemniej jednak uchwyciła kilka indywidualnych cech wskazanej postaci, składających się na całościowy wizerunek króla Jerozolimy na kartach Aleksjady. 


\section{Bibliografia}

\section{Ź RÓDEA DRUKOWANE}

Albert of Aachen, Historia Ierosolimitana, History of the Journey to Jerusalem, ed. and transl. S.B. Edgington, Oxford 2007.

An Arab-Syrian Gentleman and Warrior in the period of the Crusades: Memoirs of Usamah ibn-Munqidh (Kitab al-Ptibar), transl. P.K. Hitti, New York 1929 [przedruk 2000].

Anna Komnena, Aleksjada, przekł. O. Jurewicz, t. I-II, Wrocław-Warszawa 2005.

Annae Comnenae Alexias, eds D.R. Reinsch, A. Kambylis, vol. I-II, Berolini-Novi Eboraci 2001.

Anonymi Synopsis Chronike, ed. K. Sathas, Paris 1894 [przedruk: Athens 1972].

Dölger F., Regesten der Kaiserurkunden des oströmischen Reiches, Bd. II (Regesten von 1025-1204), Berlin-München 1925 [bearbeitet von Peter Wirth, München 1995].

Fulcheri Carnotensis Historia Hierosolymitana (1095-1127), ed. H. Hagenmeyer, Heidelberg 1913.

Gesta Francorum et aliorum Hierosolimitanorum, ed. H. Hagenmeyer, Heidelberg 1890.

Guillelmi Archiepiscopi Tyrensis Chronicon, ed. R.B.C. Huygens, Turnhout 1986.

Ibn al-Asir, Extrait de la chronique intitulée Kamel-Altevarykh par Ibn-Alatyr, [w:] Recueil des historiens des croisades. Historiens orientaux, t. I, Paris 1872, s. 187-744.

Ioannis Cinnami Epitome: Rerum ab Ioannes et Alexio [sic recte Michaele]. Comnenis Gestarum, ed. A. Meineke, Bonnae 1836.

Ioannis Zonarae Epitome historiarum libri XIII-XVIII, ed. Th. Büttner-Wobst, Bonnae 1897.

Kamal al-Din, Extraits de la chronique d'Alep, [w:] Recueil des historiens des croisades. Historiens orientaux, t. III, Paris 1884, s. 577-690.

Korespondencja arcybiskupa Teofylakta Ochrydzkiego, [w:] Testimonia najdawniejszych dziejów Słowian. Seria grecka, z. 4 (Pisarze z VIII-XII wieku), wyd. A. Brzóstkowska, W. Swoboda, Warszawa 1997, s. 181-292.

Le „Liber" de Raymond d'Aguilers, eds J.H. Hill, L.L. Hill, Paris 1969.

Matthew of Edessa, Armenia and the Crusades, Tenth to Twelfth Centuries: The Chronicle of Matthew of Edessa, transl. A.E. Dostourian, Lanham-New York-London 1993.

Michaelis Glycae Annales, ed. I. Bekker, Bonnae 1836.

Nicetae Choniatae Historia, ed. J.-L. van Dieten, Berolini-Novi Eboraci 1975.

Piotr Tudebod, Historia de Hierosolymitano Itinere, eds J.H. Hill, L.L. Hill, Paris 1977.

The Damascus Chronicle of the Crusades. Extracted and Translated from the Chronicle of Ibn Al-Qalanisi, ed. H.A.R. Gibb, New York 1932 [przedruk 2014]. 
Theodori Prodromi Scripta Miscellanea, [w:] Patrologia Graeca, vol. CXXXIII, ed. J.P. Migne, Paris 1864, col. 1344-1350.

\section{Opracowania}

Ahrweiler H., Byzantine Concepts of the Foreigner: The case of the Nomads, [w:] Studies on the Internal Diaspora of the Byzantine Empire, eds H. Ahrweiler, A. Laiou, Dumbarton Oaks 1998, s. 1-15.

Albu E., Bohemond and the Rooster: Byzantines, Normans, and the Artful Ruse, [w:] Anna Komnene and Her Times, ed. T. Gouma-Peterson, London-New York 2000, s. 157-168.

Amouroux-Mourad M., Le Comté d'Édesse (1098-1150), Paris 1988.

Anna Komnene and Her Times, ed. T. Gouma-Peterson, London-New York 2000.

Brett M., The Battles of Ramla (1099-1105), [w:] Egypt and Syria in the Fatimid, Ayyubid and Mamluk Eras. Proceedings of the $1^{\text {st }}, 2^{\text {nd }}$, and $3^{\text {rd }}$ international colloquium organized at the Katholieke Universiteit Leuven in May 1992, 1993, and 1994, eds U. Vermeulen, D. De Smet, K. d'Hulster, Leuven 1995, s. 17-39.

Browning R., An unpublished funeral oration on Anna Comnena, [w:] Aristotle Transformed: The Ancient Commentators and Their Influence, ed. R. Sorabji, London 1990, s. 393-406.

Buckler G., Anna Comnena. A Study, London 1929.

Buckley P., The Alexiad of Anna Komnene: Artistic Strategy in the Making of a Myth, Cambridge 2014.

Dudek J., Postawa arystokracji bizantyjskiej wobec idei krucjat w drugiej połowie XI wieku, [w:] Rycerstwo Europy środkowo-wschodniej wobec idei krucjat, red. W. Peltz, J. Dudek, Zielona Góra 2002, s. 139-158.

Edgington S.B., Baldwin I of Jerusalem, 1100-1118, Abingdon-New York 2019.

Ferdinandi S., La Contea Franca di Edessa. Fondazione e Profilo Storico del Primo Principato Crociato nel Levante (1098-1150), Rome 2017.

Ferrier L., La couronne refusée de Godefroy de Bouillon: eschatologie et humiliation de la majesté au premier temps du royaume latin de Jérusalem, [w:] Le concile de Clermont de 1095 et l'appel à la croisade. Actes du Colloque Universitaire International de Clermont-Ferrand (23-25 juin 1995), Rome 1997, s. 245-265.

Flori J., Bohémond d'Antioche: Chevalier d'aventure, Paris 2007.

France J., Anna Comnena, the Alexiad and the First Crusade, „Reading Medieval Studies" 1984, vol. X, s. 20-38.

France J., The Election and Title of Godfrey de Bouillon, „Canadian Journal of History" 1983, vol. XVIII, No. 3, s. 321-329.

Frankopan P., Perception and Projection of Prejudice: Anna Comnena, the Alexiad and the First Crusade, [w:] Gendering the Crusades, eds S.B. Edgington, S. Lambert, Cardiff 2001, s. 59-76.

Gautier P., L'obituaire du typikon du Pantokrator, „Revue des études byzantines” 1969 , t. XXVII, no. 1, s. 235-262.

Hagenmeyer H., Chronologie de la première croisade (1094-1100), Paris 1902. 
Hermans J., The Byzantine View of the Normans - Another Norman Myth?, „Anglo-Norman Studies" 1979, vol. II, s. 78-92.

Hill J.H., Hill L.L., The Convention of Alexius Comnenus and Raymond of Saint Gilles, „The American Historical Review” 1953, vol. LVIII, No. 2, s. 322-327.

Howard-Johnston J., Anna Komnene and the Alexiad, [w:] Anna Komnene and Her Times, ed. T. Gouma-Peterson, London-New York 2000, s. 232-302.

Kambylis A., Zum Programm der byzantinischen Historikerin Anna Komnene, [w:] Dorema: Hans Diller zum 70. Geburtstag: Dauer und Überleben des antiken Geistes, hrsg. K. Vourveres, A.D. Skiadas, Athens 1975, s. 127-146.

Kazhdan A., Latins and Franks in Byzantium: Perception and Reality from the Eleventh to the Twelfth Century, [w:] The Crusades from the Perspective of Byzantium and the Muslim World, eds A. Laiou, R.P. Mottahedeh, Washington, D.C. 2001, s. 83-100.

Kokoszko M., Kanon portretowania $w$ historiografii bizantyńskiej na przykładzie portretu Boemunda w „Aleksjadzie” Anny Komneny, „Acta Universitatis Lodziensis. Folia Historica" 2000, z. 67, s. 59-73.

Kolovou I., Anna Komnene and the Alexiad: The Byzantine Princess and the First Crusade, Barnsley 2020.

Lechner K., Hellenen und Barbaren im Weltbild der Byzantiner, München 1955.

Lilie R.-J., Anna Komnene und die Lateiner, „Byzantinoslavica” 1993, t. LIV, s. 169-182.

Loud G.A., Anna Komnena and her Sources for the Normans of Southern Italy, [w:] Church and Chronicle in the Middle Ages. Essays Presented to John Taylor, eds G.A. Loud, I.N. Wood, London 1991, s. 41-57.

Macrides R., The Pen and the Sword: Who Wrote the Alexiad?, [w:] Anna Komnene and Her Times, ed. T. Gouma-Peterson, London-New York 2000, s. 63-81.

Mayer H.E., Études sur l'histoire de Baudouin Ier, roi de Jérusalem, [w:] Mélanges sur l'histoire du royaume latin de Jérusalem (Mémoires de l'Académie des inscriptions et Belles Lettres, Nouvelle série 5), Paris 1984, s. 10-91.

McQueen W.B., Relations between the Normans and Byzantium, 1071-1112, „Byzantion” 1986, vol. LVI, s. 427-476.

Mesko M., Boje Byzancie s Pecenehmi o Trakiu v rokoch 1088 az 1091, „Vojenska Historia" 2007, t. I, s. 3-27.

Murray A.V., Daimbert of Pisa, the Domus Godefridi and the Accession of Baldwin I of Jerusalem, [w:] Clermont to Jerusalem: The Crusades and Crusader Societies 1095-1500, ed. A.V. Murray, Turnhout 1998, s. 81-102.

Murray A.V., The Army of Godfrey of Bouillon, 1096-1099: Structure and Dynamics of a Contingent on the First Crusade, „Revue belge de philologie et d'histoire" 1992, t. LXX, no. 2, s. 301-329.

Murray A.V., The Crusader Kingdom of Jerusalem: A Dynastic History 1099-1125, Oxford 2000.

Murray A.V., The Title of Godfrey of Bouillon as Ruler of Jerusalem, „Collegium Medievale" 1990, vol. III, s. 163-167.

Neville L., Anna Komnene: The Life and Work of a Medieval Historian, Oxford 2016. 
Neville L., Heroes and Romans in Twelfth-Century Byzantium: The "Material for History" of Nikephoros Bryennios, Cambridge 2012.

Papageorgiou A., The political ideology of John II Komnenos, [w:] John II Komnenos, Emperor of Byzantium: In the Shadow of Father and Son, ed. A. Bucosssi, A.R. Suarez, Abingdon-New York 2016, s. 37-52.

Papaioannou S., Anna Komnene's Will, [w:] Byzantine Religious Culture: Studies in Honor of Alice-Mary Talbot, eds D. Sullivan, E. Fisher, S. Papaioannou, Leiden-Boston 2012, s. 99-124.

Pełech T., Obraz „obcego” w Aleksjadzie Anny Komneny. Przypadek Normanów, Wrocław 2016.

Reinsch D.R., Women's Literature in Byzantium? The Case of Anna Komnene, [w:] Anna Komnene and Her Times, ed. T. Gouma-Peterson, London-New York 2000, s. 83-105.

Ricoeur P., Język, tekst, interpretacja. Wybór pism, przekł. P. Graff, K. Rosner, Warszawa 1989.

Riley-Smith J., The Title of Godfrey of Bouillon, „Bulletin of the Institute of Historical Research” 1979, vol. LII, No. 125, s. 83-86.

Rösch G., Der „Kreuzzug” Bohemundus gegen Dyrrachion 1107/1108 in der leteinischen Tradition des 12. Jahrhunderts, „Römische Historische Mitteilungen” 1984, Bd. XXVI, s. 181-190.

Rubenstein J., Godfrey of Bouillon Versus Raymond of Saint-Gilles: How Carolingian Kingship Trumped Millenarianism at the End of the First Crusade, [w:] The Legend of Charlemagne in the Middle Ages, eds M. Gabriele, J. Stuckey, New York 2008, s. 59-75.

Runciman S., Dzieje wypraw krzyżowych, t. II (Królestwo Jerozolimskie i frankijski Wschód 1100-1187), przekł. J. Schwakopf, Katowice 2009.

Russo L., Boemondo. Figlio di Guiscardo e principe di Antiochia, Avellino 2009.

Shepard J., When Greek meets Greek: Alexius Comnenus and Bohemond in 1097-98, „Byzantine and Modern Greek Studies” 1988, vol. XII, s. 185-278.

Shepard J., "Father” or „scorpion”? Style and substance in Alexios's diplomacy, [w:] Alexios I Komnenos: Papers of the second Belfast Byzantine International Colloquium, 14-16 April 1989, eds M. Mullet, D. Smythe, Belfast 1996, s. $68-132$.

Shepard J., Cross-Purposes: Alexius Comnenus and the First Crusade, [w:] The First Crusade: Origins and Impact, ed. J. Phillips, Manchester 1997, s. 107-129.

Sinclair K., Anna Komnene and her Sources for Military Affairs in the Alexiad, „Estudios bizantinos” 2014, vol. II, s. 143-185.

Stephenson P., Anna Comnena's Alexiad as a Source for the Second Crusade? "Journal of Medieval History” 2003, vol. XXIX, s. 41-54.

Stephenson P., Byzantium's Balkan Frontier: A political Study of the Northern Balkans, 900-1204, Cambridge 2000.

Stouraitis I., Conceptions of War and Peace in Anna Comnena's Alexiad, [w:] Byzantine War Ideology between Roman Imperial Concept and Christian Religion: Akten des Internationalen Symposiums (Vienna, 19-21 Mai 2011), eds J. Koder, I. Stouraitis, Vienna 2012, s. 69-80. 
Strzelczyk J., „W purpurze urodzona” - Anna Komnena i Aleksjada, [w:] J. Strzelczyk, Pióro w wattych dłoniach. O twórczości kobiet $w$ dawnych wiekach, t. II, Warszawa 2007, s. 148-194.

Tanner H.J., In his Brothers' Shadow: The Crusading Career and Reputation of Eustace III of Boulogne, [w:] The Crusades: Other Experiences, Alternate Perspectives, ed. K.I. Semann, Binghamton 2003, s. 83-99.

Theotokis G., Bohemond of Taranto: Crusader and Conqueror, Barnsley 2020.

The Oxford Dictionary of Byzantium, vol. I-III, ed. A. Kazhdan, Oxford-New York 1991.

Thomas R.D., Anna Comnena's account of the First Crusade, „Byzantine and Modern Greek Studies" 1991, vol. XV, s. 269-312.

Tibble S., Crusader Armies: 1099-1187, New Haven-London 2018.

Tycner-Wolicka M., Opowieść o wizerunku z Edessy. Cesarz Konstantyn Porfirogeneta i nieuczyniony ręka wizerunek Chrystusa, Kraków 2009.

Tyerman Ch., God's War. A New History of the Crusades, London-New York 2007.

Vučetić M.M., Emperor John Ir's encounters with foreign rulers, [w:] John II Komnenos, Emperor of Byzantium: In the Shadow of Father and Son, ed. A. Bucosssi, A.R. Suarez, Abingdon-New York 2016, s. 71-90.

Wierzbiński S., Szlachetni, odważni, dzicy? Obraz Waregów i Franków w oczach Bizantyńczyków w X-XI w., „Vox Patrum” 2018, R. LXIX, s. 647-679.

NOTKA O AUTORZE:

Dr Tomasz Pełech - absolwent Uniwersytetu Wrocławskiego oraz Université Clermont-Auvergne. W ramach programu cotutelle przygotował i w 2020 r. obronił $\mathrm{z}$ wyróżnieniem pracę doktorska pt. Shaping the Image of Enemy-Infidel in the Relations of Eyewitnesses and Participants of the First Crusade: The Case of Muslims (promotorzy: prof. prof. Stanisław Rosik, Jean-Luc Fray i Damien Carraz).

Zainteresowania naukowe: wyprawy krzyżowe, Bizancjum oraz literatura i umysłowość ludzi średniowiecza.

\ tomaszpelech.nysa@gmail.com 